\title{
Evaluation of Ride Comfort for Passengers by Means of Computer Simulation
}

\section{Ján Dižo}

Faculty of Mechanical Engineering, University of Žilina. Univerzitná 8215/1, 01026 Žilina. Slovak Republic. E-mail: jan.dizo@fstroj.uniza.sk

An important aspect of rail vehicle dynamic analysis is a ride comfort analysis and a prediction when passengers and cargo can experience adverse conditions. The computational software utilisation helps to determine forces and accelerations in various positions through the body of the rail vehicle in order to predict ride properties or evaluate ideas for ride comfort in advance. This paper is aimed to the dynamic simulation of the rail vehicle running on a real track. The rail vehicle model creation, computations performance and determination of accelerations badly needed for the ride comfort evaluation is performed by SIMPACK package. Parameters of passenger rail vehicle model correspond to the four-axle two-bogie BR481 rail vehicle. The track model on that the vehicle has been run corresponds to the real track section in Slovakia.

Keywords: Ride comfort, Rail vehicle, Computer simulation

\section{Acknowledgement}

This paper was created during the processing of the project No. APVV-0842-11: "Equivalent railway operation load simulator on the roller rig". The work is also supported by the Scientific Grant Agency of the Ministry of Education of the Slovak Republic and the Slovak Academy of Sciences in project No. 1/0347/12: “Railway wheel tread profile wear research under the rail vehicle in operation conditions simulation on the test bench.”, project No. 1/0383/12: “The rail vehicle running properties research with the help of a computer simulation." and No. 1/1098/11: "Stress Distribution in a Braked Railway Wheel”.

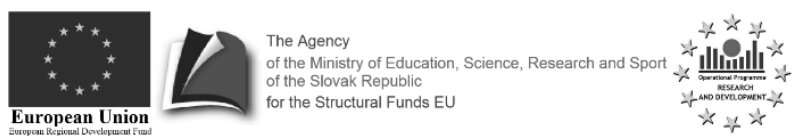

This paper was published with the financial support of the European Union. „We support research activities in Slovakia / Project is co-financed from EU sources” Project Title: „Development of two types of freight wagons with bogies for non-standard wheelbase or track wheelset, complying with the criteria for interoperability, Environmental Issues, safety and reliability“ ITMS 26220220070.

\section{References}

[1] DIŽO, J., GERLICI, J., LACK, T. (2011). State of the art tools for railway vehicles systems dynamical analysis performance. In TRANSCOM 2011: 9-th European conference of young research and scientific workers: Žilina, June 27-29, 2011, Slovak Republic, University of Žilina, Žilina. ISBN 978-80-554-0375-5, pp. 35-38.

[2] EN 12299:2009 (2009). Railway Applications - Ride Comfort for Passengers - Measurement and Evaluation, European Committee for Standardization, Brussels.

[3] GERLICI, J. (2013). Comfort for passenger of rail vehicle assessment. In: Advanced methods in computational and experimental mechanics. London: Pearson Education Limited. ISBN 978-1-78434-069-8, pp. 141 - 172.

[4] GERLICI, J., LACK, T. (2014). Modified HHT method for vehicle vibration analysis in time domain utilisation. In: Applied Mechanics and Materials. Vol. 486. Trans Tech Publications, Switzerland doi:10.4028/www.scientific.net/AMM.486.396. Volume Experimental stress Analysis 51, 2014. ISBN 978-3-03785-977-3, pp. $396-405$.

[5] GERLICI, J., LACK, T. (2008). Modified HHT Method Usage for Vehicle Vibration Analysis in Time Domain. Communication - Scientific letters of the University of Žilina, 2/2008, EDIS - Publishers of University of Žilina, Žilina, 2008. ISSN 1335-4205, pp. 26-32.

[6] GERLICI, J., LACK, T. (2007). Methods for Vehicle Vibration Analysis in Time Domain. Prace naukowe Politechniki Warszawskiej. Z. 63, Transport. Publishing House of the Warsaw University of Technology. Warszawa, 2007. ISSN 1230-9265, pp. 71-81. 
[7] GERLICI, J., LACK, T. (2007). An analysis of bumpers and springs parameters influence on the ride comfort. In: Dynamics of rigid and deformable bodies 2007. Proceedings V. international conference (In Slovak). J. E. Purkyně University in Ústí nad Labem, Ústí nad Labem. ISBN 978-80-7044-914-1, pp. 39-48.

[8] GERLICI, J., LACK, T. (2003). Railway wheel and rail geometry influence on ride properties of the vehicle. (In Slovak) In: 16. International conference „Current problems in rail vehicles - PRORAIL 2003“, EDIS, Žilina. ISBN 80-968823-6-8, pp. 163-171.

[9] GERLICI, J., LACK, J., ONDROVÁ, Z. (2007). Evaluation of comfort for passengers of railway vehicles. Communication Scientific Letters of the University of Žilina, 4/2007, Žilina, 2007. ISSN 1335-4205, pp. 44-49.

[10] LACK, T. (2013): Wheel/rail contact integration phenomena for vehicles in track dynamics evaluation. In: Advanced methods in computational and experimental mechanics. London: Pearson Education Limited. ISBN 978-178434-069-8, pp. $113-140$.

[11] LACK, T., GERLICI, J. (2008). Analysis of Vehicles Dynamic Properties from the Point of View of Passenger Comfort. Communication - Scientific letters of the University of Žilina, 2/2008, EDIS - Publishers of University of Žilina, Žilina, 2008. ISSN 1335-4205, pp. 10-18.

[12] LACK, T., GERLICI, J. (2007). Vehicles Dynamical Properties Analysis from the Point of View of Comfort for Passengers. In: Archives of Transport. Vol. 19, issue 1-2, Poland. ISSN 8066-9546, pp. 91-110.

[13] ONDROVÁ, Z. GERLICI, J., LACK, T. (2007). Comfort for passengers of railway vehicle analysis. In: Proceedings of international conference "TRANSCOM 2007", proceedings, Section 7, EDIS - Publishers of University of Žilina, Žilina. ISBN 978-80-8070-696-8, pp. 205-210.

[14] SIMPACK Documentation (2013). Release 9.3, 2013, User's manual.

[15] SKOČILASOVÁ, B., SKOČILAS, J., SOUKUP, J. (2008). Experimental determination of natural frequencies and stiffness of suspension of flexible mounted body, application on road and railway vehicles (In Czech). Acta Mechanica Slovaca, No. 3-B/2008, CD ROM, vol. 12, Košice, 2008. ISSN 1335-2393, pp. 715 - 726.

[16] SKOČILAS, J., SKOČILASOVÁ, B., SOUKUP, J. (2011). Investigation of the vehicle model mechanical vibration. (In Czech) $9^{\text {th }}$ international conference Dynamics of rigid and deformable bodies 2011, FPTM J. E. Purkyně University in Ústí nad Labem, CD - ROM, 2011. ISBN 978-80-7414-376-2, 12 pages.

[17] SVOBODA, M., SKOČILASOVÁ, B. (2010). Analytical analysis of vertical vibration of mechanical system of bodies. Presentation of Proceedings of Extended Abstracts of 26th Conference with International Participation Computational Mechanics 2010, University of West Bohemia in Plzeň, Hrad Nečtiny, November, 2010.

[18] ŠŤASTNIAK, P., HARUŠINEC, J. (2014). Simulation analysis of selected parameters by the development of nonstandard freight wagon. In: Experimental and Computational Methods, I. international conference for young scientists, Ustí nad Labem, Czech Republic, J. E. Purkyně University in Ústí nad Labem, CD-ROM. ISBN 978-807414-725-8, pp. 89-96.

[19] ŠŤASTNIAK, P., HARUŠINEC, J. (2013). Computer Aided Simulation Analysis for Computation of Modal Analysis of the Freight Wagon. In: Communications: scientific letters of the University of Žilina. - Vol. 15, no. 4, 2013. ISSN 1335-4205, pp. $73-79$. 